\title{
Holistic understanding of contemporary ecosystems requires integration of data on domesticated, captive and cultivated organisms
}

\author{
Quentin Groom,§, Tim Adriaens', Sandro Bertolino", Kendra Phelps", Jorrit H Poelen ${ }^{\text {a }}$, \\ DeeAnn Marie Reeder", David M Richardson§, Nancy B Simmons”, Nathan Upham ^ \\ ‡ Meise Botanic Garden, Meise, Belgium \\ $\S$ Centre for Invasion Biology, Department of Botany and Zoology, Stellenbosch University, Stellenbosch, South Africa \\ | Research Inst. for Nature and Forest (INBO), Brussels, Belgium \\ II Department of Life Sciences and Systems Biology, University of Turin, Torino, Italy \\ \# EcoHealth Alliance, New York, United States of America \\ a Ronin Institute for Independent Scholarship, Montclair, United States of America \\ « Bucknell University, Lewisburg, United States of America \\ " Department of Mammalogy, Division of Vertebrate Zoology, American Museum of Natural History, New York, \\ United States of America \\ ^Arizona State University, Tempe, United States of America
}

Corresponding author: Quentin Groom (quentin.groom@plantentuinmeise.be)

Academic editor: Vincent Smith

Received: 02 Mar 2021 | Accepted: 13 May 2021 | Published: 15 Jun 2021

Citation: Groom Q, Adriaens T, Bertolino S, Phelps K, Poelen JH, Reeder DM, Richardson DM, Simmons NB, Upham N (2021) Holistic understanding of contemporary ecosystems requires integration of data on domesticated, captive and cultivated organisms . Biodiversity Data Journal 9: e65371.

https://doi.org/10.3897/BDJ.9.e65371

\begin{abstract}
Domestic and captive animals and cultivated plants should be recognised as integral components in contemporary ecosystems. They interact with wild organisms through such mechanisms as hybridization, predation, herbivory, competition and disease transmission and, in many cases, define ecosystem properties. Nevertheless, it is widespread practice for data on domestic, captive and cultivated organisms to be excluded from biodiversity repositories, such as natural history collections. Furthermore, there is a lack of integration of data collected about biodiversity in disciplines, such as agriculture, veterinary science, epidemiology and invasion science. Discipline-specific data are often intentionally excluded from integrative databases in order to maintain the "purity" of data on natural processes.
\end{abstract}


Rather than being beneficial, we argue that this practise of data exclusivity greatly limits the utility of discipline-specific data for applications ranging from agricultural pest management to invasion biology, infectious disease prevention and community ecology. This problem can be resolved by data providers using standards to indicate whether the observed organism is of wild or domestic origin and by integrating their data with other biodiversity data (e.g. in the Global Biodiversity Information Facility). Doing so will enable efforts to integrate the full panorama of biodiversity knowledge across related disciplines to tackle pressing societal questions.

\section{Keywords}

Darwin core, interoperability, invasive species, One Health, urban ecology

\section{Introduction}

Even by conservative estimates, $29 \%$ of the global land surface has been significantly modified by anthropogenic activities (Ellis 2011). On some continents, such as Europe, the percentage is much higher (Ellis et al. 2020). Agriculture, urbanisation and forestry are all anthropogenic activities that create or radically transform ecosystems. Furthermore, people further modify these ecosystems through the introduction and management of animals and plants. Domesticated animals, captive animals and cultivated plants are introduced for the production of food and other materials, but also for other qualities, including companionship, beauty, entertainment and shelter. Even semi-natural ecosystems are often maintained by domestic herbivores to restore ecosystem function and conserve habitats. Vast areas are grazed by cattle and sheep, while others are planted with food crops, such as wheat, corn, soybean, sunflower, sugar cane and rice or commercial forests of (mostly non-native) trees for timber and other forest products. Moreover, urban ecosystems are where a wide array of plant species, many of which are non-native, are cultivated in gardens for their aesthetic qualities. Such plants create important habitats and food sources for insect pollinators and other animals. Most of the earth's human population lives in what is effectively an anthropogenic biome in which introduced organisms constitute a high proportion of the total biomass. For example, the biomass of livestock on the planet has been calculated to be more than an order of magnitude larger than the biomass of all wild mammals (Bar-On et al. 2018).

In this context, we examine the importance of integrating data on domestic and captive animals and cultivated plants by reviewing interactions with their wild counterparts. We also demonstrate how some citizen science projects reject or actively discourage observations of domestic, captive and cultivated organisms and how biodiversity data, collected by agriculture, horticulture and veterinary disciplines, are not integrated with other biodiversity datasets.

Here we briefly review the importance of data on the distributions and populations of domestic organisms for tackling some of the global ecological challenges and we make 
recommendations as to how the situation can be improved. We define domestic organisms as those organisms that would not exist at a particular location were it not for human intervention and where every part of their life cycle is managed, including their food, shelter, reproduction and ultimately harvesting, by humans. Despite the intense management of domestic organisms, interactions with wild organisms frequently occur and consequently play an integral role in shaping ecosystems.

\section{Predation, parasitism and herbivory}

Domestic organisms can have significant negative impacts on native biodiversity when they are allowed to roam freely. In Italy, as in many countries, domestic cats (Felis catus) predate more than 200 other species, routinely killing birds, mammals, reptiles and amphibians (Mori et al. 2019). Domestic dogs (Canis lupus familiaris) can be an equally important predator (Holderness-Roddam and McQuillan 2014) and cause major disturbance to wildlife (Banks and Bryant 2007, Weston and Stankowich 2013). Domestic animals can also be the target of predation and parasitism from wild animals (Gazzola et al. 2005, Walker et al. 2018). Agricultural ecosystems can "subsidize" predators, which then return to adjacent wild ecosystems and impact wild prey species (Rand et al. 2006). For example, in the case of vampire bats (Desmodus rotundus) in Argentina, their population is twice as large in cattle-producing ecosystems compared to natural ecosystems, presumably due to the high density of an additional source of food (Delpietro et al. 1992). Furthermore, subsidies of food from domestic livestock can shift the diet of apex predators away from wild prey and, as a consequence, wild prey populations are no longer controlled by predators (Ciucci et al. 2020).

Herbivory by livestock can also have a major impact on ecosystems. Grassland covers between $12 \%$ and $21 \%$ of the global land surface and the population of cattle is close to a billion head (FAO 2020, Robinson et al. 2011). Expanding livestock production necessitates the conversion of existing ecosystems, such as slash-and-burn methods used to clear forests, replacing native grasslands with non-native pasture plants or introducing livestock in natural grasslands to create additional pasture for cattle grazing. Anthropogenic ecosystems are often a complex patchwork of land-use types, often with distinct boundaries between the different management regimes, including grazing (Hobbs et al. 2014). Nevertheless, spillover of herbivores between natural and anthropogenic ecosystems is extensive and goes in both directions (Blitzer et al. 2012).

The direct impacts of domestic organisms on ecosystems do not just involve mammals. Fish and shellfish are frequently stocked in natural waterways and coastal areas for recreational fishing, biocontrol or their aesthetic qualities. Introduced fish can alter natural ecosystems through interactions with native species, including increased competition and/ or predation. For example, stocked brown trout (Salmo trutta) can reduce native invertebrate communities, even if those stocked fish are unable to create viable populations (Alexiades and Kraft 2017). Cultivated crops and other non-native trees and garden plants are a significant component of many anthropogenic ecosystems. They provide critical food resources for many wild species, particularly where habitat has been 
reduced through fragmentation (e.g. Chaves and Bicca-Marques 2017). Crop pests are also an important source of food for many animals, such as Brazilian free-tailed bats (Tadarida brasiliensis) which feed extensively on corn earworm moths (Helicoverpa zea) (McCracken et al. 2012).

The characteristics of cultivated plants and the way that they are grown is likely to have a large influence on whether the plants have a positive or negative impact on wild organisms. For example, crop and forestry monocultures can have negative consequences for wild bees, whereas domestic gardens may provide benefits (Kaluza et al. 2016, Samnegård et al. 2011). Furthermore, the keeping of domesticated bees results in direct competition with native pollinators (Ropars et al. 2019). Plant cultivation can indirectly affect vertebrates by changing the abundance and species composition of their arthropod prey. For example, the reduced breeding success of the insectivorous Eurasian blue tit (Cyanistes caeruleus) in urban ecosystems in comparison to congeners in native woodland has been attributed to the reduced population densities and lower diversity of arthropods on non-native cultivated trees (Helden et al. 2012, Pollock et al. 2017).

\section{Genetic impacts}

Hybridization between wild organisms and their domestic counterparts is widely perceived as a threat to the conservation of native biodiversity. It occurs, for example, between wild canids and domesticated dogs (Leonard et al. 2013) and between wild and domestic mink (Neovison vison) (Kidd et al. 2009) and, in both examples, the introgressed alleles may be deleterious for threatened wild populations. Similarly, stocking and aquaculture of fish can have a negative effect on the genetic diversity of wild populations of those species (Bourret et al. 2011, Bolstad et al. 2017, Gossieaux et al. 2019). Hybridization is also an issue for gene flow between crops and their wild relatives, such as potatoes (Solanum sp.) in the Andes (Scurrah et al. 2008). In agroecosystems, it has been suggested that the traits selected during the domestication of crop plants can disrupt species interactions and can create selective pressures that can drive the evolution of wild organisms (Macfadyen and Bohan 2010). Hybridization is widely acknowledged as "a stimulus for the evolution of invasiveness in plants" (Ellstrand and Schierenbeck 2000).

In contrast, others see the hybridization of closely related wild and domestic species brought into "artificial sympatry" not as a threat to genetic integrity, but as a mechanism whereby new biological entities are created that could, conceivably, be better suited than native species to new, human-dominated environments (Thomas 2013). Regardless of the directionality of genetic influences of domestic-wild hybridization, collection of data on the domestic organisms in question and on the interactions of domestic and wild organisms is critically important. 


\section{Wildlife disease}

There is ample evidence for the interchange of infectious diseases between domestic animals, including livestock (Frölich et al. 2002, Martin et al. 2011) and pets, such as cats and dogs (Clark et al. 2018, Wells et al. 2018), wild animals and humans. As an example, domestic dogs are a reservoir for Guinea worm (McDonald et al. 2020), Rickettsial diseases (Levin et al. 2012, Ng-Nguyen et al. 2020), Leishmaniases (Grimaldi and Tesh 1993), rabies virus (Lembo et al. 2008), Chagas disease (Trypanosoma cruzi) (Gürtler et al. 2007), Strongyloides stercoralis (Sanpool et al. 2020) and others. Likewise, domestic cats can transmit more than 20 diseases to humans and wild animals (Lepczyk et al. 2015). Many of these diseases are zoonotic and can cause serious illness and/or mortality in human populations. There are other examples from livestock, such as domestic pigs (Sus scrofa domesticus) mediating the transmission of the deadly Nipah virus (Nipah henipavirus) from fruit bats (Pteropus spp.) to farmers (Pulliam et al. 2012). Indeed, domestic mammals hold a central place in the network of known mammal virus associations (Wells et al. 2018). In the case of domestic chicken flocks, there is ample evidence for the exchange of viral diseases in both directions with wild birds (e.g. avian influenza) (Scott et al. 2018, Ferreira et al. 2019).

In aquatic ecosystems, aquaculture facilities not isolated from wild ecosystems have the potential to increase disease in wild fish populations. This might occur through disease spillover to wild congeners of farmed species or to other species. Captive fish populations can act as reservoirs of disease or otherwise affect disease dynamics in nearby wild populations (Bouwmeester et al. 2020). Similarly, the introduction of domesticated bees can transmit disease to wild bee species, and can even lead to local extinction of some wild species (Graystock et al. 2016, Meeus et al. 2018). Even cultivated plants can act as reservoirs of pests and diseases to wild plants, such as the spread of Knopper gall wasps (Andricus quercuscalicis) infesting English oak trees (Quercus robur) in northern Europe which is mediated through the planting of its alternate host Turkey oak (Q. cerris) (Hails and Crawley 1991).

\section{Potentially invasive species}

Cultivated plants, pets, wildfowl collections and aquarist collections are among the largest sources of invasive species (Funnell et al. 2009, Lockwood et al. 2019, Niemiera and Holle 2009). Urban ecosystems are foci for introductions of non-native species and frequently act as launching sites for invasions into surrounding natural ecosystems (Alston and Richardson 2006, McLean et al. 2017). Knowledge of species that are kept domestically or cultivated is useful for calculating the potential risk of escape and the possibility of a species becoming invasive. Arboreta and other collections of non-native species, typically located in urban ecosystems, provide opportunities to serve as sentinel sites for the identification of incipient invasions (e.g. Fanal et al. 2021). However, few databases collate open information on organisms in homes, gardens, arboreta and other collections in any particular region. Sources, such as seed catalogues, pet shop surveys, border interception 
databases and import certificates, have been used to evaluate the propagule pressure of potentially invasive species (Liang et al. 2006, Kopecký et al. 2013, van Kleunen et al. 2018). However, these sources of data tell us little about the lifespan, fecundity and frequency of pets and garden plants. As a consequence, horizon scans and risk assessments rely on scant information on trade in these organisms, but have virtually no information on the size and geographic distribution of captive populations (Bertolino et al. 2020). If observations of non-native garden plants were available, they would inform us of the environmental tolerances of these species, their co-occurrence and their interactions with other native and non-native organisms. Furthermore, ecological and economic impacts of invasive species are highly correlated across taxa and regions (Vilà et al. 2010). Therefore, data on domesticated and cultivated organisms are important for impact studies. As an example, the Asian hornet (Vespa velutina) has negative impacts on apiculture through predation at beehives (Monceau et al. 2014), yet data on the presence of the approximately 90 million global beehives of Apis (FAO 2020), often set out in natural environments or gardens, are not readily available.

\section{Urban ecology and agroecology}

Urban ecosystems and gardens are unique and interesting in their own right (Adler and Tanner 2013). In these habitats, cultivated plants and captive animals co-exist and interact directly with wild biodiversity, both native and non-native. Domestic gardens are the one type of ecosystem that most people manage; as such, their management decisions have a direct influence on local biodiversity, including the species they cultivate, the pets they keep, the birds they feed, the nest boxes and insect hotels they erect and the garden products they use (Sandström et al. 2006, Yang et al. 2019). In some highly urbanised areas, such as Flanders in Belgium, gardens occupy more total land surface than areas under conservation management, like nature reserves and forests (Vught et al. 2020). Urban ecosystems are increasingly seen as making an important contribution to climate change adaptation, ecosystem services and food security (Aerts et al. 2016, Eigenbrod and Gruda 2015). Likewise, biodiversity in managed agricultural ecosystems contributes to ecosystem services, such as pollination, soil nutrient cycling, watershed protection and carbon sequestration and many people come into contact with biodiversity in and around farmland (Jarvis et al. 2007). Schlaepfer et al. (2020) emphasise the importance of nonnative trees for their intrinsic value and their contributions to human well-being. In contrast, Potgieter et al. (2019) highlight how non-native woody plants contribute to changes in vegetation structure, sometimes even enhancing criminal activity in urban areas. Urban agroecology, the study of urban food systems, links both realms and is expected to quickly grow as a valued discipline (Altieri and Nicholls 2018). The study and management of biological invasions in urban areas require insights into the full spectrum of biodiversity that occurs in these regions (Gaertner et al. 2017).

As a demonstration of the importance of domestic organisms in urban ecosystems, we constructed a species interaction network for wild and cultivated organisms recorded at Meise Botanic Garden in Belgium. Only two domesticated animals are present in the 
Garden, honey bees (Apis mellifera) and domestic cats from neighbouring houses (Fig. 1). This network demonstrates that these two species have among the largest number of potential interactions with other organisms in the garden. Indeed, honey bees have the highest "betweenness centrality" of any species in the network. Betweenness centrality is a measure of how central a vertex is in a network, based on the number of shortest paths that travel through it. While this is only a network of potential interactions, the possibility for real impacts on the wild organisms of the Meise Botanic Garden is large.

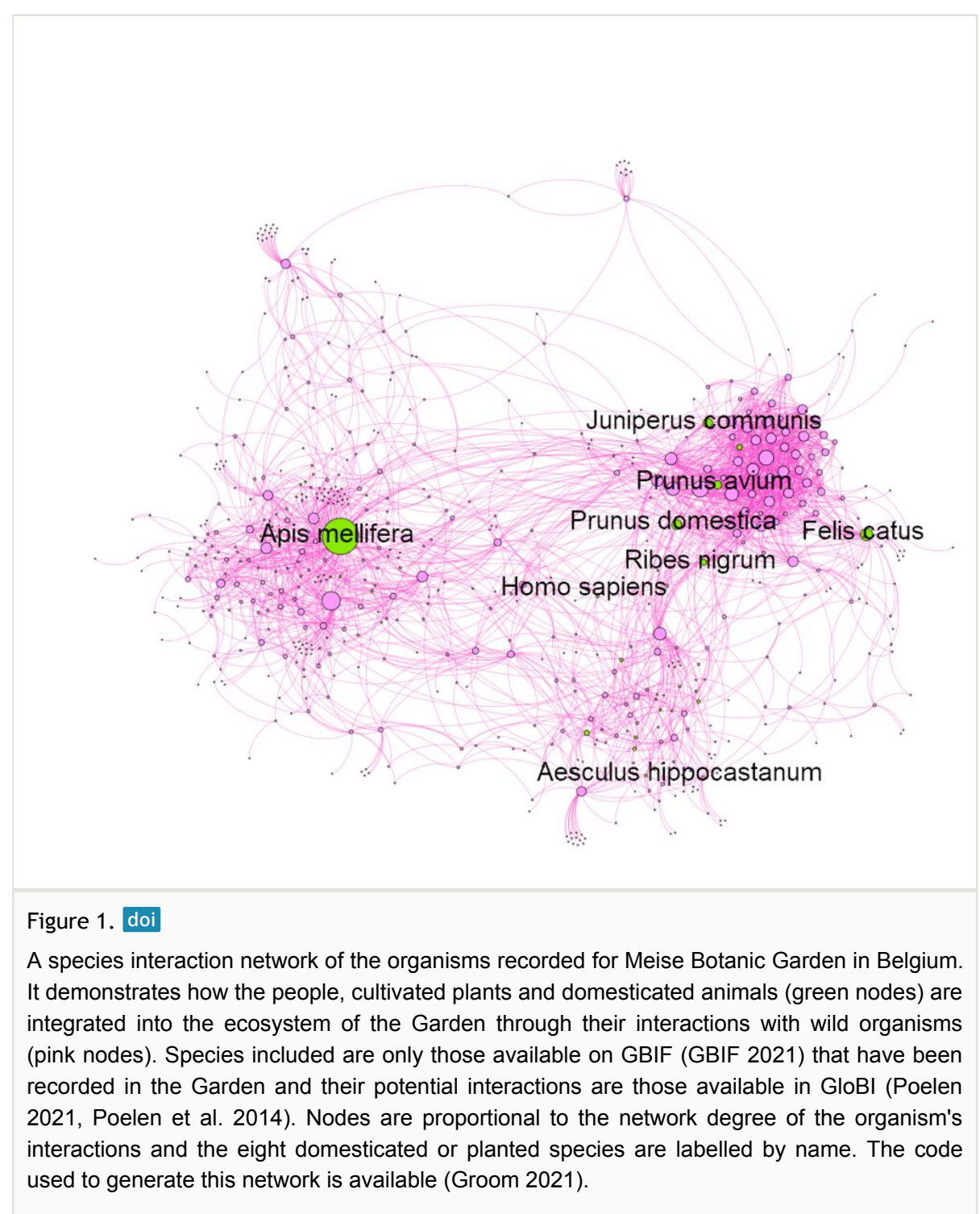




\section{Observations of domestic and cultivated species}

Volunteers are a major contributor to ecological and biogeographic data (Chandler et al. 2017, Irwin 2018, Poisson et al. 2020). The internet and smartphones have dramatically increased the possibilities for public involvement in research and so have the types of projects and types of data gathered (Adriaens 2015, Theobald et al. 2015). For some taxa, such as birds, these internet resources have become the primary source of ecological and distributional data (Sullivan et al. 2009). Given the overwhelming evidence that domestic animals and cultivated plants are an integral part of global ecosystems and that they are often the dominant species, why is it that we actively discriminate against domesticated organisms when collecting data on biodiversity? Most recording platforms targeting the naturalist community primarily aim to record only observations of wild organisms and actively reject data on domestic or cultivated species. For example, the international biodiversity recording platform, iNaturalist, states:

"The main reason we try to mark things like this [captive/cultivated] is because iNat is primarily about observing wild organisms, not animals in zoos, garden plants, specimens in drawers, etc., and our scientific data partners are often not interested in (or downright alarmed by) observations of captive or cultivated organisms. "

Any observation on iNaturalist marked captive/cultivated will never reach "Research Grade". It will, therefore, not be transferred to GBIF, even if the species identification is validated. It is germane that iNaturalist puts the responsibility for this decision on their "scientific data partners". They are not alone - eBird, the single largest contributor to GBIF, explicitly requests users not to record captive birds, escaped pets, domestic fowl and pet birds (Sullivan et al. 2009). These platform policies to include only wild organisms are not exceptional. There is considerable controversy over what should be recorded (and where), leading some local citizen science organisations to write clarifying guidelines (Walker et al. 2015).

Other citizen science initiatives have bucked the trend and have specifically tried to survey the occurrence of alien and native plants in gardens (e.g. Dehnen-Schmutz and Conroy 2018, Pergl et al. 2016). Such surveys provide a measure of propagule pressure or the potential of introduced species to establish and thrive, which may explain the establishment success of these species outside gardens.

The gaps in available data on domestic/captive/invasive species are plainly evident in GBIF. For example, there are approximately 26 billion chickens (Gallus gallus domesticus) in the world (FAO 2020), but only 55,000 observations on GBIF. For comparison, the rare, endangered and localised bearded vulture (Gypaetus barbatus) has almost the same number $(54,000)$. Clearly, recording chickens in commercial chicken barns may not be useful for ecological analyses, but recording free-ranging chickens in rural and urban ecosystems may well be. 


\section{The causes and solutions}

There is no doubt that all organisms, be they native, non-native, growing wild, in captivity or in cultivation, are important components of biodiversity. Suggestions on how to deal with data in these different categories have generated lively debate among biologists. For example, Schlaepfer (2018), in a paper entitled "Do non-native species contribute to biodiversity?" proposed that "biodiversity and sustainability indices should include all species". This suggestion was vigorously opposed by a group of invasion ecologists who argued that this approach "will reduce our capacity to detect the effects of non-native species on native biodiversity with potentially devastating consequences" (Pauchard et al. 2018). There are many other examples of vigorous debate in literature on the hazards and opportunities implicit in mixing such data for various purposes (Feest et al. 2010). Schlaepfer (2018) does not clarify whether he includes domestic organisms in his view of biodiversity, but many of his arguments still apply.

Part of the reason for the artificial demarcation between wild and domestic/cultivated organisms is the divisions of research domains, industrial sectors and their respective regulatory bodies. Researchers and managers in agriculture, animal husbandry, the pet trade, epidemiology, conservation, forestry, ecology and invasion science are all interested in these data, but also generate data for their own needs. Traditionally, biodiversity observation data have been the preserve of biogeographers and conservationists and observations of cultivated and domesticated organisms are removed before creating maps and building distribution models (Gueta and Carmel 2016). Yet, as the examples above show, these data have much broader uses in research than just biogeography and conservation. Indeed, one cannot hope to understand and predict the dynamics of contemporary ecosystems without also considering the domesticated, captive and cultivated components of "the whole landscape" (sensu Hobbs et al. 2014).

For at least the past 400 years, Western culture has considered the realms of humans and nature as separate (Paterson 2006). Indeed, it has been suggested that mobile biodiversity recording apps reinforce this artificial division between humans and nature by neglecting the human-influenced aspects of nature (Altrudi 2021). Nevertheless, in recent years, the One Health approach has emerged to bring together different sectors to work together to improve human and animal health in the context of a shared environment (Atlas 2012). This approach applied to biodiversity observations would see a marked improvement in reducing the barriers that prevent the full integration of data. One could even extend this concept under a banner of 'One Biodiversity' given that the same principles of an interconnected whole apply.

Another reason for observations of domesticated organisms being excluded from biodiversity datasets is that there has lacked a means by which these observations can be distinguished from those of wild organisms. The preeminent standard used to communicate biodiversity observations is the Darwin Core standard (Wieczorek et al. 2012). Until recently, there were no unambiguous or standardised methods in Darwin Core to indicate that the organism observed was captive or cultivated; however, this oversight 
has now been changed: The Biodiversity Information Standards organisation recently ratified a proposal to add the term "degreeOfEstablishment" to the standard and for this term to use a vocabulary adapted from Blackburn et al. (2011) (see Groom et al. 2019). The publishing tools and data infrastructure, run by GBIF, will be adapted to support these new Darwin Core terms during 2021.

It is unreasonable to expect systematic observation of all domesticated organisms to be collected. Indeed, projects devoted to the study of wild organisms do not want to be swamped with large numbers of observations of pets and garden plants. However, some of these data are already collected by national and regional authorities for veterinary and agricultural statistics, pathogen surveillance and animal welfare (Table 1). Yet these data are poorly integrated with biodiversity data and are often inaccessible to biodiversity researchers. Recognition by the relevant authorities that these are important data for ecologists would help drive access to these data. Great adherence to the FAIR data principles of being Findable, Accessible, Interoperable and Reusable would improve the situation (Wilkinson et al. 2016). This would mean greater use of community standards, stable identifiers and particularly full description of the data with metadata.

Table 1.

Examples of datasets related to domestic organisms that could be incorporated into biodiversity datasets if correctly documented and standardised.

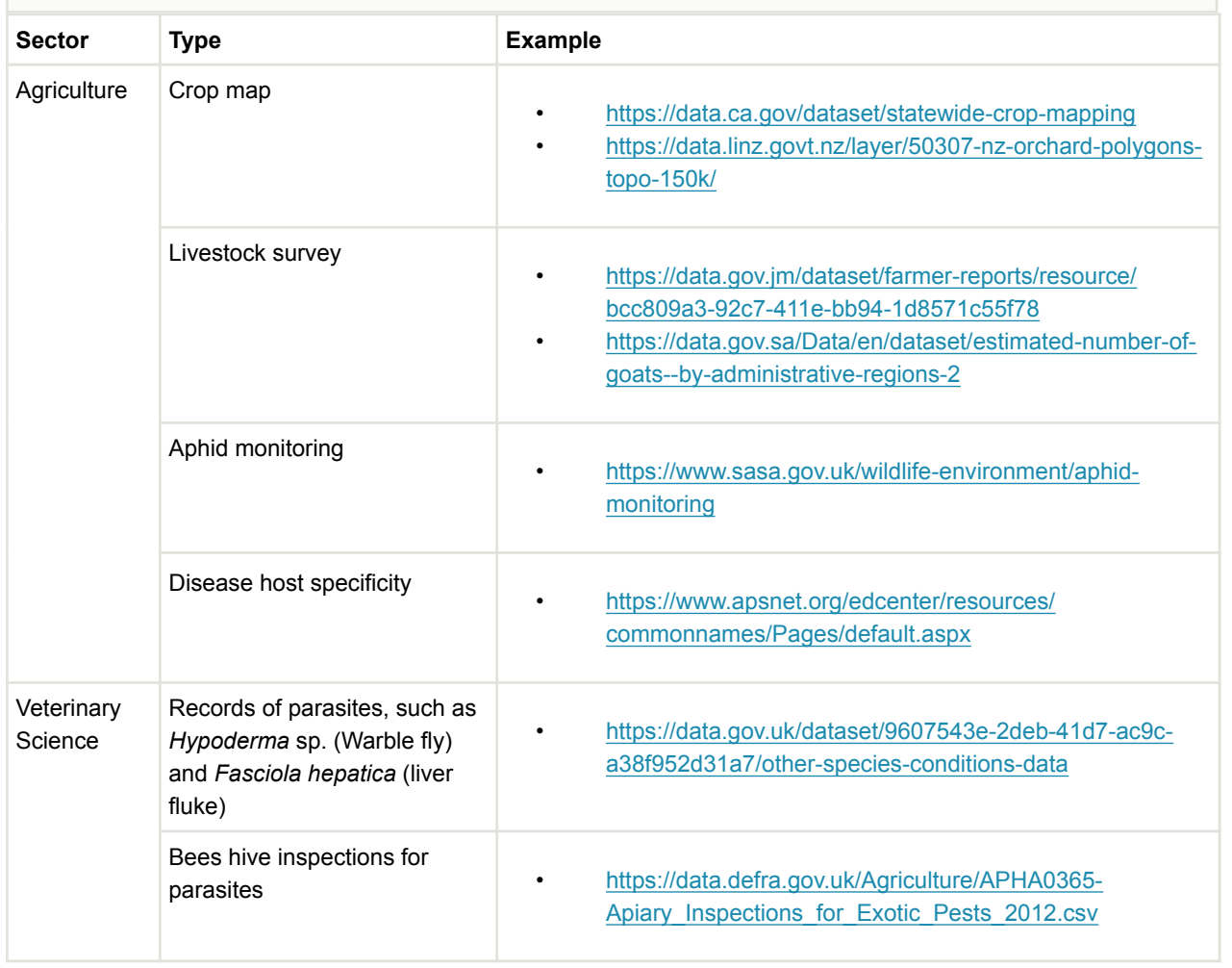




\begin{tabular}{|c|c|c|c|}
\hline Sector & Type & Exar & \\
\hline \multirow[t]{2}{*}{ Horticulture } & Inventory of botanic garden & • & $\begin{array}{l}\text { https://www.bgci.org/resources/bgci-databases/ } \\
\text { plantsearch/ }\end{array}$ \\
\hline & Observations of garden plants & - & http://doi.org/10.5281/zenodo.3514685 \\
\hline \multirow[t]{2}{*}{$\begin{array}{l}\text { Domestic } \\
\text { animals }\end{array}$} & Pets census & • & $\begin{array}{l}\text { https://datos.gob.es/en/catalogo/l01082798-animales-de- } \\
\underline{\text { compania1 }}\end{array}$ \\
\hline & Zoo inventory & • & $\begin{array}{l}\text { http://cza.nic.in/page/en/inventory-of-animals-in-zoos } \\
\text { https://www.rzss.org.uk/downloads/agm/2013/ } \\
\text { EZ Inventory AGM2013.pdf } \\
\text { Species360 Zoological Information Management System } \\
\text { (ZIMS) (zims.Species360.org) } \\
\text { www.zootierliste.de }\end{array}$ \\
\hline
\end{tabular}

Given that a data standard now exists (i.e. Groom et al. 2019), we now recommend that data collectors and providers do not reject any data based on the organism's status of cultivation, captivity or domestication, but rather ensure that its status is adequately described using Darwin Core. Furthermore, we recommend the greater integration of all data on biodiversity, whether it is of wild or domestic origin. These data may include information on the species kept as pets, farm animals, garden plants and crops, but also pests and diseases of those species. Indeed, there is clearly much to be gained from encouraging the collection and sharing of such data on domestic organisms, their distributions, abundance, behaviour and interactions with wildlife.

In conclusion, although it is fairly self-evident to an ecologist that domestic organisms are part of ecosystems, data on these organisms remain poorly integrated into global data systems and are thus often disregarded. Yet, these data are highly relevant to solving many environmental challenges and should, therefore, be more actively gathered and shared.

\section{Acknowledgements}

We thank Wouter Addink, Ana Casino and Dimitrios Koureas for organising the COVID-19 Task Force of the Consortium of European Taxonomic Facilities (CETAF) and Distributed System of Scientific Collections (DiSSCo) and to other members of the Knowledge Hub group.

\section{Funding program}

QG and TA acknowledge the support of the Belgian Science Policy Office under the TrIAS project (BR/165/A1/TrIAS). QG, TA \& SB acknowledge COST Action CA17122 Alien CSI 
Increasing understanding of alien species through citizen science, supported by COST (European Cooperation in Science and Technology). DMR acknowledges support from the DSI-NRF Centre of Excellence for Invasion Biology and the Oppenheimer Memorial Trust (grant 18576/03). SB was funded by the University of Turin, local research grant number.

\section{Author contributions}

QG \& TA had the initial concept for the paper. QG wrote the outline and all authors developed the ideas and contributed to the final draft.

\section{Conflicts of interest}

The authors have no conflicts of interest to declare.

\section{References}

- $\quad$ Adler F, Tanner C (2013) Urban ecosystems: Ecological principles for the built environment. Cambridge University Press, Cambridge. https://doi.org/10.1017/ CBO9780511981050

- $\quad$ Adriaens T (2015) Trying to engage the crowd in recording invasive alien species in Europe: experiences from two smartphone applications in northwest Europe. Management of Biological Invasions 6 (2): 215-225. https://doi.org/10.3391/mbi. 2015.6.2.12

- $\quad$ Aerts R, Dewaelheyns V, Achten WM (2016) Potential ecosystem services of urban agriculture: a review. PeerJ Preprints 4: e2286v1. https://doi.org/10.7287/peerj. preprints.2286v1

- $\quad$ Alexiades A, Kraft C (2017) Effects of stocked trout on stream invertebrate communities. Journal of Freshwater Ecology 32 (1): 95-102. https://doi.org/ 10.1080/02705060.2016.1248502

- $\quad$ Alston K, Richardson D (2006) The roles of habitat features, disturbance, and distance from putative source populations in structuring alien plant invasions at the urban/ wildland interface on the Cape Peninsula, South Africa. Biological Conservation 132 (2): 183-198. https://doi.org/10.1016/j.biocon.2006.03.023

- Altieri MA, Nicholls $\mathrm{Cl}$ (2018) Agroecología urbana: diseño de granjas urbanas ricas en biodiversidad, productivas y resilientes. Agro Sur 46 (2): 49-60. https://doi.org/10.4206/ agrosur.2018.v46n2-07

- $\quad$ Altrudi S (2021) Connecting to nature through tech? The case of the iNaturalist app. Convergence: The International Journal of Research into New Media Technologies 27 (1): 124-141. https://doi.org/10.1177/1354856520933064

- $\quad$ Atlas R (2012) One health: Its origins and future. In: Mackenzie J, Jeggo M, Daszak P, Richt J (Eds) One health: The human-animal-environment interfaces in emerging infectious diseases. 365. Springer Berlin Heidelberg, Berlin, $13 \mathrm{pp}$.

[ISBN 978-3-642-36889-9]. https://doi.org/10.1007/82_2012_223 
- Banks PB, Bryant JV (2007) Four-legged friend or foe? Dog walking displaces native birds from natural areas. Biology Letters 3 (6): 611-613. https://doi.org/10.1098/rsbl. $\underline{2007.0374}$

- Bar-On Y, Phillips R, Milo R (2018) The biomass distribution on Earth. Proceedings of the National Academy of Sciences 115 (25): 6506-6511. https://doi.org/10.1073/pnas. 1711842115

- $\quad$ Bertolino S, Ancillotto L, Bartolommei P, Benassi G, Capizzi D, Gasperini S, Lucchesi M, Mori E, Scillitani L, Sozio G, Falaschi M, Ficetola GF, Cerri J, Genovesi P, Carnevali L, Loy A, Monaco A (2020) A framework for prioritising present and potentially invasive mammal species for a national list. NeoBiota 62: 31-54. https://doi.org/10.3897/ neobiota.62.52934

- $\quad$ Blackburn T, Pyšek P, Bacher S, Carlton J, Duncan R, Jarošík V, Wilson JU, Richardson D (2011) A proposed unified framework for biological invasions. Trends in Ecology \& Evolution 26 (7): 333-339. https://doi.org/10.1016/j.tree.2011.03.023

- Blitzer EJ, Dormann CF, Holzschuh A, Klein AM, Rand TA, Tscharntke T (2012) Spillover of functionally important organisms between managed and natural habitats. Agriculture, Ecosystems \& Environment 146 (1): 34-43. https://doi.org/10.1016/j.agee.2011.09.005

- $\quad$ Bolstad G, Hindar K, Robertsen G, Jonsson B, Sægrov H, Diserud O, Fiske P, Jensen A, Urdal K, Næsje T, Barlaup B, Florø-Larsen B, Lo H, Niemelä E, Karlsson S (2017) Gene flow from domesticated escapes alters the life history of wild Atlantic salmon. Nature Ecology \& Evolution 1 (5). https://doi.org/10.1038/s41559-017-0124

- $\quad$ Bourret V, O'Reilly PT, Carr JW, Berg PR, Bernatchez L (2011) Temporal change in genetic integrity suggests loss of local adaptation in a wild Atlantic salmon (Salmo salar) population following introgression by farmed escapees. Heredity 106 (3): 500-510. https://doi.org/10.1038/hdy.2010.165

- Bouwmeester M, Goedknegt MA, Poulin R, Thieltges D (2020) Collateral diseases: Aquaculture impacts on wildlife infections. Journal of Applied Ecology https://doi.org/ 10.1111/1365-2664.13775

- $\quad$ Chandler M, See L, Copas K, Bonde AZ, López BC, Danielsen F, Legind JK, Masinde S, Miller-Rushing A, Newman G, Rosemartin A, Turak E (2017) Contribution of citizen science towards international biodiversity monitoring. Biological Conservation 213:

280-294. https://doi.org/10.1016/j.biocon.2016.09.004

- Chaves Ó, Bicca-Marques JC (2017) Crop feeding by brown howlers (Alouatta guariba clamitans) in forest fragments: The conservation value of cultivated species. International Journal of Primatology 38 (2): 263-281. https://doi.org/10.1007/ s10764-016-9927-8

- $\quad$ Ciucci P, Mancinelli S, Boitani L, Gallo O, Grottoli L (2020) Anthropogenic food subsidies hinder the ecological role of wolves: Insights for conservation of apex predators in human-modified landscapes. Global Ecology and Conservation 21 https://doi.org/10.1016/j.gecco.2019.e00841

- $\quad$ Clark N, Seddon J, Šlapeta J, Wells K (2018) Parasite spread at the domestic animal wildlife interface: anthropogenic habitat use, phylogeny and body mass drive risk of cat and dog flea (Ctenocephalides spp.) infestation in wild mammals. Parasites \& Vectors 11 (1). https://doi.org/10.1186/s13071-017-2564-z

- Dehnen-Schmutz K, Conroy J (2018) Working with gardeners to identify potential invasive ornamental garden plants: testing a citizen science approach. Biological Invasions 20 (11): 3069-3077. https://doi.org/10.1007/s10530-018-1759-3 
- Delpietro HA, Marchevsky N, Simonetti E (1992) Relative population densities and predation of the common vampire bat (Desmodus rotundus) in natural and cattle-raising areas in north-east Argentina. Preventive Veterinary Medicine 14 (1-2): 13-20.

https://doi.org/10.1016/0167-5877(92)90080-Y

- $\quad$ Eigenbrod C, Gruda N (2015) Urban vegetable for food security in cities. A review. Agronomy for Sustainable Development 35 (2): 483-498. https://doi.org/10.1007/ s13593-014-0273-y

- Ellis E (2011) Anthropogenic transformation of the terrestrial biosphere. Philosophical Transactions of the Royal Society A: Mathematical, Physical and Engineering Sciences 369 (1938): 1010-1035. https://doi.org/10.1098/rsta.2010.0331

- $\quad$ Ellis E, Beusen AW, Goldewijk KK (2020) Anthropogenic Biomes: 10,000 BCE to 2015 CE. Land 9 (5). https://doi.org/10.3390/land9050129

- Ellstrand NC, Schierenbeck KA (2000) Hybridization as a stimulus for the evolution of invasiveness in plants? Proceedings of the National Academy of Sciences 97 (13): 7043-7050. https://doi.org/10.1073/pnas.97.13.7043

- Fanal A, Mahy G, Fayolle A, Monty A (2021) Arboreta reveal the invasive potential of several conifer species in the temperate forests of western Europe. NeoBiota 64: 23-42. https://doi.org/10.3897/neobiota.64.56027

- FAO (2020) The food and agriculture organization FAOSTAT. http://www.fao.org/faostat/ en/\#data. Accessed on: 2021-2-06.

- $\quad$ Feest A, Aldred TD, Jedamzik K (2010) Biodiversity quality: a paradigm for biodiversity. Ecological Indicators 10 (6): 1077-1082. https://doi.org/10.1016/j.ecolind.2010.04.002

- $\quad$ Ferreira H, Taylor T, Dimitrov K, Sabra M, Afonso C, Suarez D (2019) Virulent Newcastle disease viruses from chicken origin are more pathogenic and transmissible to chickens than viruses normally maintained in wild birds. Veterinary Microbiology 235: 25-34. https://doi.org/10.1016/j.vetmic.2019.06.004

- $\quad$ Frölich K, Thiede S, Kozikowski T, Jakob W (2002) A review of mutual transmission of important infectious diseases between livestock and ildlife in Europe. Annals of the New York Academy of Sciences 969 (1): 4-13. https://doi.org/10.1111/j.1749-6632. 2002.tb04343.x

- $\quad$ Funnell E, Heaton M, MacDonald F, Brownson B (2009) The aquarium and horticultural industry as a pathway for the introduction of aquatic invasive species-outreach initiatives within the Great Lakes basin. Biodiversity 10 (2-3): 104-112. https://doi.org/ 10.1080/14888386.2009.9712852

- $\quad$ Gaertner M, Wilson JR, Cadotte MW, Maclvor JS, Zenni RD, Richardson DM (2017) Non-native species in urban environments: Patterns, processes, impacts and challenges. Biological Invasions 19: 3461-3469. https://doi.org/10.1007/ s10530-017-1598-7

- $\quad$ Gazzola A, Bertelli I, Avanzinelli E, Tolosano A, Bertotto P, Apollonio M (2005) Predation by wolves (Canis lupus) on wild and domestic ungulates of the western Alps, Italy. Journal of Zoology 266 (2): 205-213. https://doi.org/10.1017/S0952836905006801

- GBIF (2021) Occurrence Download. The Global Biodiversity Information Facility. https://doi.org/10.15468/DL.BGF9GB

- Gossieaux P, Bernatchez L, Sirois P, Garant D (2019) Impacts of stocking and its intensity on effective population size in brook charr (Salvelinus fontinalis) populations. Conservation Genetics 20 (4): 729-742. https://doi.org/10.1007/s10592-019-01168-2 
- $\quad$ Graystock P, Blane E, McFrederick Q, Goulson D, Hughes WH (2016) Do managed bees drive parasite spread and emergence in wild bees? International Journal for Parasitology: Parasites and Wildlife 5 (1): 64-75. https://doi.org/10.1016/.ijppaw. 2015.10.001

- Grimaldi G, Tesh RB (1993) Leishmaniases of the New World: current concepts and implications for future research. Clinical Microbiology Reviews 6 (3): 230-250. https://doi.org/10.1128/CMR.6.3.230

- Groom Q, Desmet P, Reyserhove L, Adriaens T, Oldoni D, Vanderhoeven S, Baskauf SJ, Chapman A, McGeoch M, Walls R, Wieczorek J, Wilson J, Zermoglio PF, Simpson A (2019) Improving Darwin Core for research and management of alien species. Biodiversity Information Science and Standards 3 https://doi.org/10.3897/biss.3.38084

- Groom Q (2021) AgentschapPlantentuinMeise/gardenNetwork: submission (Version 0.1.4). 0.1.4. Zenodo. Release date: 2021-1-29. URL: https://doi.org/10.5281/zenodo. 4573274

- Gueta T, Carmel Y (2016) Quantifying the value of user-level data cleaning for big data: A case study using mammal distribution models. Ecological Informatics 34: 139-145. https://doi.org/10.1016/j.ecoinf.2016.06.001

- Gürtler RE, Cecere MC, Lauricella MA, Cardinal MV, Kitron U, Cohen JE (2007) Domestic dogs and cats as sources of Trypanosoma cruzi infection in rural northwestern Argentina. Parasitology 134 (1): 69-82. https://doi.org/10.1017/ S0031182006001259

- Hails RS, Crawley MJ (1991) The population dynamics of an alien insect: Andricus quercuscalicis (Hymenoptera: Cynipidae). The Journal of Animal Ecology 60 (2). https://doi.org/10.2307/5297

- Helden A, Stamp G, Leather S (2012) Urban biodiversity: comparison of insect assemblages on native and non-native trees. Urban Ecosystems 15 (3): 611-624. https://doi.org/10.1007/s11252-012-0231-X

- Hobbs RJ, Higgs E, Hall CM, Bridgewater P, Chapin FS, Ellis EC, Ewel JJ, Hallett LM, Harris J, Hulvey KB, Jackson ST, Kennedy PL, Kueffer C, Lach L, Lantz TC, Lugo AE, Mascaro J, Murphy SD, Nelson CR, Perring MP, Richardson DM, Seastedt TR, Standish RJ, Starzomski BM, Suding KN, Tognetti PM, Yakob L, Yung L (2014) Managing the whole landscape: historical, hybrid, and novel ecosystems. Frontiers in Ecology and the Environment 12 (10): 557-564. https://doi.org/10.1890/130300

- Holderness-Roddam B, McQuillan PB (2014) Domestic dogs (Canis familiaris) as a predator and disturbance agent of wildlife in Tasmania. Australasian Journal of Environmental Management 21 (4): 441-452. https://doi.org/10.1080/1448 6563.2014.952787

- Irwin A (2018) No PhDs needed: how citizen science is transforming research. Nature 562 (7728): 480-482. https://doi.org/10.1038/d41586-018-07106-5

- Jarvis DI, Padoch C, Cooper HD (2007) Managing biodiversity in agricultural ecosystems. Columbia University Press, New York, 492 pp. https://doi.org/10.1007/ s10745-009-9280-z

- Kaluza B, Wallace H, Heard T, Klein A, Leonhardt S (2016) Urban gardens promote bee foraging over natural habitats and plantations. Ecology and Evolution 6 (5): 1304-1316. https://doi.org/10.1002/ece3.1941 
- $\quad$ Kidd AG, Bowman J, Lesbarrères D, Schulte-Hostedde Al (2009) Hybridization between escaped domestic and wild American mink (Neovison vison). Molecular Ecology 18 (6): 1175-1186. https://doi.org/10.1111/j.1365-294X.2009.04100.x

- $\quad$ Kopecký O, Kalous L, Patoka J (2013) Establishment risk from pet-trade freshwater turtles in the European Union. Knowledge and Management of Aquatic Ecosystems https://doi.org/10.1051/kmae/2013057

- Lembo T, Hampson K, Haydon D, Craft M, Dobson A, Dushoff J, Ernest E, Hoare R, Kaare M, Mlengeya T, Mentzel C, Cleaveland S (2008) Exploring reservoir dynamics: a case study of rabies in the Serengeti ecosystem. Journal of Applied Ecology 45 (4): 1246-1257. https://doi.org/10.1111/j.1365-2664.2008.01468.x

- Leonard JA, Echegaray J, Randi E, Vil C (2013) Impact of hybridization with domestic dogs on the conservation of wild canids. Free-ranging dogs and wildlife conservation 170 https://doi.org/10.1093/acprof:osobl/9780199663217.003.0007

- Lepczyk C, Lohr C, Duffy D (2015) A review of cat behavior in relation to disease risk and management options. Applied Animal Behaviour Science 173: 29-39.

https://doi.org/10.1016/j.applanim.2015.07.002

- Levin M, Killmaster L, Zemtsova G (2012) Domestic dogs (Canis familiaris) as reservoir hosts for Rickettsia conorii. Vector-Borne and Zoonotic Diseases 12 (1): 28-33.

https://doi.org/10.1089/vbz.2011.0684

- $\quad$ Liang S, Chuang L, Chang M (2006) The pet trade as a source of invasive fish in Taiwan. Taiwania 51 (2): 93-98. https://doi.org/10.6165/tai.2006.51(2).93

- Lockwood JL, Welbourne DJ, Romagosa CM, Cassey P, Mandrak NE, Strecker A, Leung B, Stringham OC, Udell B, Episcopio-Sturgeon DJ, Tlusty MF, Sinclair J, Springborn MR, Pienaar EF, Rhyne AL, Keller R (2019) When pets become pests: the role of the exotic pet trade in producing invasive vertebrate animals. Frontiers in Ecology and the Environment 17 (6): 323-330. https://doi.org/10.1002/fee.2059

- Macfadyen S, Bohan D (2010) Crop domestication and the disruption of species interactions. Basic and Applied Ecology 11 (2): 116-125. https://doi.org/10.1016/j.baae. 2009.11.008

- Martin C, Pastoret P, Brochier B, Humblet M, Saegerman C (2011) A survey of the transmission of infectious diseases/infections between wild and domestic ungulates in Europe. Veterinary Research 42 (1). https://doi.org/10.1186/1297-9716-42-70

- McCracken G, Westbrook J, Brown V, Eldridge M, Federico P, Kunz T (2012) Bats track and exploit changes in insect pest populations. PLOS One 7 (8). https://doi.org/10.1371/ journal.pone.0043839

- McDonald R, Wilson-Aggarwal J, Swan GF, Goodwin CD, Moundai T, Sankara D, Biswas G, Zingeser J (2020) Ecology of domestic dogs Canis familiaris as an emerging reservoir of Guinea worm Dracunculus medinensis infection. PLOS Neglected Tropical Diseases 14 (4). https://doi.org/10.1371/journal.pntd.0008170

- McLean P, Gallien L, Wilson JU, Gaertner M, Richardson D (2017) Small urban centres as launching sites for plant invasions in natural areas: insights from South Africa. Biological Invasions 19 (12): 3541-3555. https://doi.org/10.1007/s10530-017-1600-4

- Meeus I, Pisman M, Smagghe G, Piot N (2018) Interaction effects of different drivers of wild bee decline and their influence on host-pathogen dynamics. Current Opinion in Insect Science 26: 136-141. https://doi.org/10.1016/j.cois.2018.02.007 
- Monceau K, Bonnard O, Thiéry D (2014) Vespa velutina: a new invasive predator of honeybees in Europe. Journal of Pest Science 87 (1): 1-16. https://doi.org/10.1007/ s10340-013-0537-3

- Mori E, Menchetti M, Camporesi A, Cavigioli L, Fatis K, Girardello M (2019) License to kill? Domestic cats affect a wide range of native fauna in a highly biodiverse Mediterranean country. Frontiers in Ecology and Evolution 7: 477. https://doi.org/ 10.3389/fevo.2019.00477

- $\quad$ Ng-Nguyen D, Hii S, Hoang MT, Nguyen VT, Rees R, Stenos J, Traub RJ (2020) Domestic dogs are mammalian reservoirs for the emerging zoonosis flea-borne spotted fever, caused by Rickettsia felis. Scientific Reports 10 (1). https://doi.org/10.1038/ s41598-020-61122-y

- $\quad$ Niemiera A, Holle BV (2009) Invasive plant species and the ornamental horticulture industry. In: Inderjit (Ed.) Management of Invasive Weeds. 5. Springer Netherlands, Dordrecht. [ISBN 978-1-4020-9201-5 978-1-4020-9202-2]. https://doi.org/10.1007/ 978-1-4020-9202-2 9

- Paterson B (2006) Ethics for wildlife conservation: Overcoming the human-nature dualism. BioScience 56 (2). https://doi.org/10.1641/0006-3568(2006) 056[0144:EFWCOT]2.0.CO;2

- Pauchard A, Meyerson L, Bacher S, Blackburn T, Brundu G, Cadotte M, Courchamp F, Essl F, Genovesi P, Haider S, Holmes N, Hulme P, Jeschke J, Lockwood J, Novoa A, Nuñez M, Peltzer D, Pyšek P, Richardson D, Simberloff D, Smith K, van Wilgen $B$, Vilà M, Wilson JU, Winter M, Zenni R (2018) Biodiversity assessments: Origin matters. PLOS Biology 16 (11). https://doi.org/10.1371/journal.pbio.2006686

- Pergl J, Sdlo J, Petk P, Danihelka J, Chrtek J, Hejda M, Moravcov L, Perglov I, Tajerov K, Pyek P (2016) Dark side of the fence: ornamental plants as a source of wild-growing flora in the Czech Republic. Preslia 88 (2).

- Poelen J, (2021) Global biotic interactions: Interpreted data products. Zenodo. Version Number: 0.2 type: dataset DOI: 10.5281/ZENODO.3950589. URL: https://zenodo.org/ record/3950589

- Poelen JH, Simons JD, Mungall CJ (2014) Global biotic interactions: An open infrastructure to share and analyze species-interaction datasets. Ecological Informatics 24: 148-159. https://doi.org/10.1016/j.ecoinf.2014.08.005

- Poisson AC, McCullough IM, Cheruvelil KS, Elliott KC, Latimore JA, Soranno PA (2020) Quantifying the contribution of citizen science to broad-scale ecological databases. Frontiers in Ecology and the Environment 18 (1): 19-26. https://doi.org/10.1002/fee. $\underline{2128}$

- $\quad$ Pollock C, Capilla-Lasheras P, McGill RR, Helm B, Dominoni D (2017) Integrated behavioural and stable isotope data reveal altered diet linked to low breeding success in urban-dwelling blue tits (Cyanistes caeruleus). Scientific Reports 7 (1). https://doi.org/ 10.1038/s41598-017-04575-y

- Potgieter L, Gaertner M, O'Farrell P, Richardson D (2019) Does vegetation structure influence criminal activity? Insights from Cape Town, South Africa. Frontiers of Biogeography 11 (1). https://doi.org/10.21425/F5FBG42035

- Pulliam JC, Epstein J, Dushoff J, Rahman S, Bunning M, Jamaluddin A, Hyatt A, Field $H$, Dobson A, Daszak P (2012) Agricultural intensification, priming for persistence and the emergence of Nipah virus: a lethal bat-borne zoonosis. Journal of The Royal Society Interface 9 (66): 89-101. https://doi.org/10.1098/rsif.2011.0223 
- Rand T, Tylianakis J, Tscharntke T (2006) Spillover edge effects: the dispersal of agriculturally subsidized insect natural enemies into adjacent natural habitats. Ecology Letters 9 (5): 603-614. https://doi.org/10.1111/j.1461-0248.2006.00911.x

- $\quad$ Robinson TP, P.K. T, Franceschini G, Kruska RL, Chiozza F, Notenbaert A, Cecchi G, Herrero M, Epprecht M, Fritz S, You L, Conchedda G, See L (2011) Global livestock production systems. Food and Agriculture Organization of the United Nations (FAO) and International Livestock Research Institute (ILRI), Rome, 152 pp.

URL: http://www.fao.org/3/i2414e/i2414e00.htm [ISBN 978-92-5-107028-4]

- Ropars L, Dajoz I, Fontaine C, Muratet A, Geslin B (2019) Wild pollinator activity negatively related to honey bee colony densities in urban context. PLOS One 14 (9). https://doi.org/10.1371/journal.pone.0222316

- $\quad$ Samnegård U, Persson A, Smith H (2011) Gardens benefit bees and enhance pollination in intensively managed farmland. Biological Conservation 144 (11): 2602-2606. https://doi.org/10.1016/j.biocon.2011.07.008

- Sandström UG, Angelstam P, Mikusiński G (2006) Ecological diversity of birds in relation to the structure of urban green space. Landscape and Urban Planning 77 (1-2): 39-53. https://doi.org/10.1016/j.landurbplan.2005.01.004

- Sanpool O, Intapan PM, Rodpai R, Laoraksawong P, Sadaow L, Tourtip S, Piratae S, Maleewong W, Thanchomnang T (2020) Dogs are reservoir hosts for possible transmission of human strongyloidiasis in Thailand: molecular identification and genetic diversity of causative parasite species. Journal of Helminthology 94 https://doi.org/ 10.1017/S0022149X1900107X

- Schlaepfer M (2018) Do non-native species contribute to biodiversity? PLOS Biology 16 (4). https://doi.org/10.1371/journal.pbio.2005568

- Schlaepfer M, Guinaudeau B, Martin P, Wyler N (2020) Quantifying the contributions of native and non-native trees to a city's biodiversity and ecosystem services. Urban Forestry \& Urban Greening 56 https://doi.org/10.1016/j.ufug.2020.126861

- $\quad$ Scott AB, Phalen D, Hernandez-Jover M, Singh M, Groves P, Toribio JML (2018) Wildlife presence and interactions with chickens on Australian commercial chicken farms assessed by camera traps. Avian Diseases 62 (1): 65-72. https://doi.org/ 10.1637/11761-101917-Reg.1

- $\quad$ Scurrah M, Celis-Gamboa C, Chumbiauca S, Salas A, Visser RF (2008) Hybridization between wild and cultivated potato species in the Peruvian Andes and biosafety implications for deployment of GM potatoes. Euphytica 164 (3): 881-892. https://doi.org/ 10.1007/s10681-007-9641-x

- Sullivan B, Wood C, lliff M, Bonney R, Fink D, Kelling S (2009) eBird: A citizen-based bird observation network in the biological sciences. Biological Conservation 142 (10): 2282-2292. https://doi.org/10.1016/j.biocon.2009.05.006

- Theobald EJ, Ettinger AK, Burgess HK, DeBey LB, Schmidt NR, Froehlich HE, Wagner C, HilleRisLambers J, Tewksbury J, Harsch MA, Parrish JK (2015) Global change and local solutions: Tapping the unrealized potential of citizen science for biodiversity research. Biological Conservation 181: 236-244. https://doi.org/10.1016/..biocon. 2014.10.021

- Thomas C (2013) The Anthropocene could raise biological diversity. Nature 502 (7469): 7-7. https://doi.org/10.1038/502007a

- $\quad$ van Kleunen M, Essl F, Pergl J, Brundu G, Carboni M, Dullinger S, Early R, GonzálezMoreno P, Groom Q, Hulme P, Kueffer C, Kühn I, Máguas C, Maurel N, Novoa A, 
Parepa M, Pyšek P, Seebens H, Tanner R, Touza J, Verbrugge L, Weber E, Dawson W, Kreft H, Weigelt P, Winter M, Klonner G, Talluto M, Dehnen-Schmutz K (2018) The changing role of ornamental horticulture in alien plant invasions: Horticulture and plant invasions. Biological Reviews 93 (3): 1421-1437. https://doi.org/10.1111/brv.12402

- Vilà M, Basnou C, Pyšek P, Josefsson M, Genovesi P, Gollasch S, Nentwig W, Olenin S, Roques A, Roy D, Hulme PE (2010) How well do we understand the impacts of alien species on ecosystem services? A pan-European, cross-taxa assessment. Frontiers in Ecology and the Environment 8 (3): 135-144. https://doi.org/10.1890/080083

- Vught I, Wils C, Schneiders A (2020) Bescherming en beheer in Vlaanderen. Mededelingen van het Instituut voor Natuuren Bosonderzoek 2: 79-88. URL: https://www.vlaanderen.be/publicaties/natuurrapport-2020

- Walker J, Evans K, Rose Vineer H, van Wyk J, Morgan E (2018) Prediction and attenuation of seasonal spillover of parasites between wild and domestic ungulates in an arid mixed-use system. Journal of Applied Ecology 55 (4): 1976-1986. https://doi.org/ 10.1111/1365-2664.13083

- Walker K, Pearman D, Stroh P (2015) Where and what do we record? https://bsbi.org/ wp-content/uploads/dlm uploads/Where and what do we record.pdf. Accessed on: 2020-12-27.

- Wells K, Gibson D, Clark N, Ribas A, Morand S, McCallum H (2018) Global spread of helminth parasites at the human-domestic animal-wildlife interface. Global Change Biology 24 (7): 3254-3265. https://doi.org/10.1111/gcb.14064

- Weston MA, Stankowich T (2013) Dogs as agents of disturbance. In: Gompper M (Ed.) Free-ranging dogs and wildlife onservation. Oxford University Press, Oxford, 336 pp. URL: https://global.oup.com/academic/product/free-ranging-dogs-and-wildlifeconservation-9780199663217?cc=nl\&lang=en\& [ISBN 9780199663217].

- Wieczorek J, Bloom D, Guralnick R, Blum S, Döring M, Giovanni R, Robertson T, Vieglais D (2012) Darwin Core: An evolving community-developed biodiversity data standard. PLOS One 7 (1). https://doi.org/10.1371/journal.pone.0029715

- Wilkinson M, Dumontier M, Aalbersberg IJ, Appleton G, Axton M, Baak A, Blomberg N, Boiten J, da Silva Santos LB, Bourne P, Bouwman J, Brookes A, Clark T, Crosas M, Dillo I, Dumon O, Edmunds S, Evelo C, Finkers R, Gonzalez-Beltran A, Gray AG, Groth P, Goble C, Grethe J, Heringa J, 't Hoen PC, Hooft R, Kuhn T, Kok R, Kok J, Lusher S, Martone M, Mons A, Packer A, Persson B, Rocca-Serra P, Roos M, van Schaik R, Sansone S, Schultes E, Sengstag T, Slater T, Strawn G, Swertz M, Thompson M, van der Lei J, van Mulligen E, Velterop J, Waagmeester A, Wittenburg P, Wolstencroft K, Zhao J, Mons B (2016) The FAIR Guiding Principles for scientific data management and stewardship. Scientific Data 3 (1). https://doi.org/10.1038/sdata.2016.18

- $\quad$ Yang L, Turo K, Riley C, Inocente EA, Tian J, Hoekstra N, Piermarini P, Gardiner M (2019) Can urban greening increase vector abundance in cities? The impact of mowing, local vegetation, and landscape composition on adult mosquito populations. Urban Ecosystems 22 (5): 827-839. https://doi.org/10.1007/s11252-019-00857-7 